\title{
Production and Optimization of Pectinase from Pectinolytic Fungi Cultivated on Mango peels and Pectin Subjected to Submerged Fermentation
}

\author{
Kelemu Mulluye ${ }^{1, *}$, Ameha Kebede ${ }^{2}$, Negussie Bussa ${ }^{3}$ \\ ${ }^{1}$ Department of Central laboratory, College of ULMD; \\ ${ }^{2}$ Department of Biological Science and Biotechnology, College of Natural and Computational Sciences; \\ ${ }^{3}$ Department of Food Science and Post-Harvest Technology, Institute of Technology; \\ Haramaya University, Ethiopia. \\ Corresponding author* \\ kelemumuluye@gmail.com
}

Manuscript received: 14 December, 2020. Revision accepted: 25 June, 2021. Published: 02 July, 2021

\begin{abstract}
Pectinases are the group of enzymes that degrade pectin. This study was conducted with the aim of isolation of efficient pectinase producing pectinolytic fungi from the decomposing mango peels using extracted mango peels pectin as a growth substrate under submerged fermentation, determining optimum pectinase production conditions with regards to some physicochemical parameters. The organisms were screened for the production of pectinase using Pectin agar media, and the two active pectinolytic fungi $\left(\mathrm{P}_{1}\right.$ and $\left.\mathrm{P}_{2}\right)$ were isolated. pectinase production media was later used for the Lab scale production of pectinase by inoculating $\mathrm{p}_{1}$ and $\mathrm{p}_{2}$ and incubating for 7 days. The enzyme was extracted after seven days of fermentation and every day tested for their pectinolytic activity. $\mathrm{P}_{2}$ showed relatively higher pectinolytic activity and was therefore used for further studies. $\mathrm{P}_{2}$ was inoculated into a broth containing mango pectin under submerged fermentation. Results indicate that a pectin yield of mango peel 17.75\%. Different parameters optimization processes were investigated on submerged fermentation namely $\mathrm{pH}$, incubation period, temperature and substrate concentration optima were found 6,4 days, $35^{\circ} \mathrm{C}$ and $1.5 \%$ respectively. The result suggests that mango peels have high pectin content and can be used for the value-added synthesis of pectinase.
\end{abstract}

Keywords: Mango peels; Pectinase; Pectin; Submerged fermentation.

\section{INTRODUCTION}

Enzymes are biological catalysts that are prerequisite for various chemical reactions produced by plants, animals and microbes. They are specific for carrying out a task and efficiently speedup the rate of reaction ultimately accelerates all metabolic processes. Microbial enzymes are gaining consideration with the current development of enzyme technology (Gurung et al., 2013). As nature has vast potential of microbial enzyme resource and enzymes from microbes are of great significance in developing bioprocesses for industries. There is continuous increasing demand for industrial enzymes with the rising need for sustainable solutions (Adrio and Demain, 2014).

Pectinases are among the first enzymes to be used at home. Their commercial application was first observed in 1930 for the preparation of wines and fruit juice. Pectinase are today one of the upcoming enzymes of the commercial sector. It has been reported that microbial pectinase account for $25 \%$ of the global food enzymes sales (Jayani et al., 2005). Pectinase, that break down pectin is a well-known term for commercial enzyme preparation; a polysaccharide substrate, found in the cell wall of plants. This enzyme splits polygalacturonic acid into monogalacturonic acid by opening glycosidic linkages. Through this process, it softens the cell wall (Khan et al., 2012).

Plants and microorganisms are two major sources of the pectinase enzyme. But, microbial source of pectinase has become increasingly important from both technical and economic point of view. Among microbes, fungi as enzyme producers have many advantages since they are normally GRAS (generally regarded as safe) microorganisms and their enzymes are extracellular which makes it easy recuperation from fermentation broth (Murthy and Naidu,2010).

Maximum yield of pectinase can be achieved using agricultural wastes. The use of waste products is economically viable. Furthermore, the production can also be increased after optimization of fermentation conditions and different cultural parameters (Bibi et al. 2016). Optimization of different physicochemical parameters, including incubation period, temperature, $\mathrm{pH}$, carbon, and nitrogen sources for selected fungal 
strains, is a key step for the enhanced production of pectinase (Neeta et al., 2011).

Mango peel is one of the major by-products from the mango pulp processing industries. During the processing of mango fruit, peel and stone are generated as waste (40-50\% of total fruit mass). Waste generated from mango processing constitutes $20-25 \%$ peel, which was found to be a good source for the extraction of pectin of good quality, with a high degree of esterification and phenolic compounds (Berardini et al., 2005). Pectin acts as the inducer for the production of pectinase enzymes by microbial systems, and pectin-rich mango peels are considered to be a good source for pectinase production and ideal substrate for the decomposition of mango peels by microorganisms (Kumar et al., 2012).

Many urban areas in Ethiopia have simple fruit/juice processing cottage industries which usually discard mango peels after extracting the flesh for mango juice. These produce a huge amount of waste throughout the year. These waste materials can be constructively used to produce important products including pectin and pectinases as a replacement for dumping them in the environment where they might at times generate pollution. This is a promising way of converting wastes to wealth. Therefore, Optimization of in-vitro production of pectinase by pectinolytic fungi using pectin obtained from mango peels as growth substrate under submerged fermentation. Desired to extract partially purified pectin from powdered mango peels, isolate and screen active pectinolytic fungi from decaying vegetables and fruits as well as from soils containing decomposed mango peels, and optimize the effect of some physicochemical parameters.

\section{MATERIALS AND METHODS}

\section{Substrate Preparation}

Mango (Mangifera indica) peels were collected from Tsega Fruit and Juice House of Harar City, Ethiopia. The peels were washed and cut into small pieces and then treated with $97 \%$ ethanol to reduce the microbial load. The ethanol treated peels were washed with distilled water and sun-dried for 7 days. The dried peels were then ground to a powder using a milling machine and stored in a clean container at room temperature until used for extraction.

\section{Extraction of Pectin from Mango Peels}

Pectin was extracted using the method described by McCready (1970) as cited by Ezugwu et al. (2014). One hundred gram ground mango peels were weighed into a $2000 \mathrm{~mL}$ beaker containing $800 \mathrm{~mL}$ of distilled water and $12 \mathrm{~g}$ of sodium hexa-metaphosphate. The $\mathrm{pH}$ adjusted with $3 \mathrm{~N} \mathrm{HCl}$ to $2.2 \pm 0.1$. The mixture was heated in a water bath at $70^{\circ} \mathrm{C}$ for $1 \mathrm{hr}$ and stirred with a stirrer. The extract was filtered through a muslin cloth and the residue washed with $200 \mathrm{~mL}$ of distilled water. The washings were added to the filtrate. The filtrate was concentrated by evaporation on a hot plate to $1 / 5^{\text {th }}$ of the initial volume. The concentrated pectin was cooled to $50^{\circ} \mathrm{C}$ and poured into a volume of 0.5 $\mathrm{M}$ HCl-ethanol (1:3), solution. The mixture was stirred for $30 \mathrm{~min}$ and allowed to stand for $1 \mathrm{hr}$. The precipitate was vacuum filtered, washed with $\mathrm{HCl}$-ethanol solution and finally washed with acetone to remove traces of $\mathrm{HCl}$ and ethanol. The extract was dried in an oven at $40^{\circ} \mathrm{C}$ for a few hours to constant weight, finely ground and then used as mango pectin.

$$
\% \text { Yield of pectin }=\frac{\text { Amount of pectin obtained }(\mathrm{g})}{\text { Total Amount of mango peel powder used }(\mathrm{g})} \times 100
$$

\section{Collection of Soil Samples Containing Decomposing Mango Peels}

Soil samples were collected from dumping sites of decompose waste that contained mango peels at Addis Ababa, Koshe massive garbage dump, Ethiopia, using the methods described by Martin et al. (2004). The soil samples were collected in a clean dry plastic container and transported to the laboratory.

\section{Preparation of Broth Media}

Soil samples (3 g) collected from the site of decomposing/ decaying fruit and vegetable containing mango peels were homogenized in sterile medium containing $1 \%$ mango pectin, $0.14 \%$ of $\left(\mathrm{NH}_{4}\right)_{2} \mathrm{SO}_{4}$, $0.2 \%$ of $\mathrm{K}_{2} \mathrm{HPO}_{4}, 0.02 \%$ of $\mathrm{MgSO}_{4} .7 \mathrm{H}_{2} \mathrm{O}, 0.1 \%$ of nutrient solution containing $5 \mathrm{mg} / \mathrm{L} \quad \mathrm{FeSO}_{4} .7 \mathrm{H}_{2} \mathrm{O}, 1.6$ $\mathrm{mg} / \mathrm{L} \mathrm{MnSO}_{4} \cdot \mathrm{H}_{2} \mathrm{O}, 1.4 \mathrm{mg} / \mathrm{L} \mathrm{ZnSO}_{4} .7 \mathrm{H}_{2} \mathrm{O}, 2.0 \mathrm{mg} / \mathrm{L}$ $\mathrm{CoCl}_{2}$. The mixture was at $30{ }^{\circ} \mathrm{C}$ for 24 hours.

\section{Preparation of Solid Media}

The pectin agar medium (PAM) contained $1 \%$ mango pectin, $0.14 \%$ of $\left(\mathrm{NH}_{4}\right) 2 \mathrm{SO}_{4}, 0.2 \%$ of $\mathrm{K}_{2} \mathrm{HPO}_{4}, 0.02 \%$ of $\mathrm{MgSO}_{4} .7 \mathrm{H}_{2} \mathrm{O}, 0.1 \%$ of nutrient solution containing; 5 $\mathrm{mg} / \mathrm{L} \mathrm{FeSO} 4.7 \mathrm{H}_{2} \mathrm{O}, 1.6 \mathrm{mg} / \mathrm{L} \mathrm{MnSO}_{4} . \mathrm{H}_{2} \mathrm{O}, 1.4 \mathrm{mg} / \mathrm{L}$ $\mathrm{ZnSO}_{4} .7 \mathrm{H}_{2} \mathrm{O}, 2.0 \mathrm{mg} / \mathrm{L} \mathrm{CoCl} \mathrm{Cl}_{2}$ and $3 \%$ agar-agar (the gelling agent) (w/v). The medium was autoclaved at 121 ${ }^{\circ} \mathrm{C}$ for $15 \mathrm{~min}$. It was allowed to cool to about $45{ }^{\circ} \mathrm{C}$ and then poured into sterile Petri dishes and allowed to gel. The plates were then incubated in an incubator at $37^{\circ} \mathrm{C}$ overnight to check for sterility (Ezugwu et al., 2014). 
Inoculation of Plates and Sub-culturing

A loop of homogenized culture from the broth medium was streaked onto the solid medium under the flame of Bunsen burner. Streaks were made from each side of the plate, marking an initial point, with sterilization of the wire loop after each side has been completed. The plates were thereafter incubated at $35{ }^{\circ} \mathrm{C}$ till visible colonies were observed. All morphologically contrasting colonies were purified by repeated streaking and subculturing on separate plates. This process was continued till pure fungal cultures were obtained (Ezugwu et al., 2013).

\section{Storage of Pure Fungal Isolates}

Pure fungal isolates were maintained on potato dextrose agar (PDA) slopes or slants as stock cultures. PDA media were prepared according to the manufacturer's specification. In the latter, $3.9 \mathrm{~g}$ of PDA powder was weighed and added in a small volume of distilled water and made up to $100 \mathrm{~mL}$. This was boiled and simultaneously stirred until a clear solution of molten PDA was produced.

\section{Microscopic and Macroscopic Features of the Isolated Fungi and Identification}

Three days old pure cultures were examined. The colour, nature of mycelia or spores and growth patterns were also observed. The three days old pure culture was used in preparing microscopic slides. A little bit of the mycelia was dropped on the slide and a drop of lactophenol blue was added to it. A cover-slip was placed over it and examination was performed under the light microscope at X400 magnification. Identification was carried out by relating features and the micrographs to identification of common Aspergillus species (Klich, 2002).

\section{The Fermentation Broth}

Pectinase was produced by submerged fermentation according to the method of Martin et al. (2004). Submerged fermentation (SmF) technique was employed using a $250 \mathrm{~mL}$ Erlenmeyer flask containing $100 \mathrm{~mL}$ of sterile cultivation medium optimized for pectinase with $0.1 \% \mathrm{NH}_{4} \mathrm{NO}_{3}, 0.1 \% \mathrm{NH}_{4} \mathrm{H}_{2} \mathrm{PO}_{4}, 0.1 \%$ $\mathrm{MgSO}_{4} .7 \mathrm{H}_{2} \mathrm{O}$ and $1 \%$ mango pectin. The flask was covered with aluminium foil and autoclaved at $121{ }^{\circ} \mathrm{C}$ for $15 \mathrm{~min}$.

\section{Inoculation of the Broth}

From the PDA slants, fresh plates were prepared and inoculated. Three days old cultures were used to inoculate the flasks. In every sterile flask, two discs of the respective fungal isolates were added using a cork borer of diameter $10 \mathrm{~mm}$ and then plugged properly. The culture was incubated for 7 days at $30^{\circ} \mathrm{C}$.

\section{Extracting the Crude Enzyme}

At each day of extract, flasks were selected from the respective groups and mycelia biomass separated using filtration technique. The broth was filtered through cheesecloth followed by Whatman No. 1 filter paper. Each day, the filtrate was analysed for pectinase activity till the $7^{\text {th }}$ day of fermentation.

\section{Pectinase Assay}

Pectinase activity was evaluated by assaying for polygalacturonase (PG) activity of the enzyme. This was achieved by measuring the release of reducing groups from pectin using 3, 5-dinitrosalicylic acid (DNS) reagent assay method described by Miller (1959) as cited in Wang et al. (1997). The reaction mixture containing $0.5 \mathrm{~mL}$ of $0.5 \%$ pectin in $0.05 \mathrm{M}$ sodium acetate buffer of $\mathrm{pH} 5.0$ and $0.5 \mathrm{~mL}$ of enzyme solution was incubated for $1 \mathrm{hr}$. One $\mathrm{ml}$ of DNS reagent was added and the reaction was stopped by boiling the mixture in a boiling water bath for 10 min. The volume of the mixture was made up to $4 \mathrm{~mL}$ with $1 \mathrm{~mL}$ of $1.4 \mathrm{M}$ of Rochelle salt (sodium potassium tartrate) solution and $1 \mathrm{~mL}$ of distilled water. The reaction mixture was allowed to cool and the absorbance was read at $575 \mathrm{~nm}$. One unit of enzyme activity was defined as the amount of enzyme that catalyses the release of one micromole of galacturonic acid per minute.

\section{Optimization of Physicochemical Parameter for Pectinase Production}

The isolate was grown under different temperature, $\mathrm{pH}$, and substrate concentration to evaluate the influence of growth conditions on pectinase production. The optimization was carried out according to Meena et al. (2015), with slight modification. Thus when one parameter (e.g. Temperature) was evaluated for its effect on pectinase production the other parameters (e.g. pH, and incubation period) were kept constant at 5 and 96 hours, respectively, and similarly, when the effect of $\mathrm{pH}$ was evaluated, the other two parameters (i.e. temperature and incubation period) were kept constant at $30{ }^{\circ} \mathrm{C}$ and 96 hours, respectively.

Effect of Temperature on the Production of Pectinase The isolate was inoculated into a $50 \mathrm{~mL}$ production medium kept in $250 \mathrm{~mL}$ capacity Erlenmeyer flask and was subsequently incubated in an incubator whose temperatures are adjusted to $25,30,35,40,45,50$ and $55{ }^{\circ} \mathrm{C}$ with the aim of determining the optimum temperature required for the production of the pectinase.The liquid medium was prepared by weighing $1 \mathrm{~g}$ of the extracted mango pectin and mixing with $0.1 \mathrm{~g}$ of $\mathrm{NH}_{4} \mathrm{NO}_{3}, \quad 0.1 \mathrm{~g}$ of $\mathrm{NH}_{4} \mathrm{H}_{2} \mathrm{PO}_{4}, \quad 0.1 \mathrm{~g}$ of $\mathrm{MgSO}_{4} \cdot 7 \mathrm{H}_{2} \mathrm{O}$, and $100 \mathrm{~mL}$ distilled water. The mixture was then autoclaved at $121{ }^{\circ} \mathrm{C}$ for $15 \mathrm{~min}$. The medium was cooled to room temperature in a 
bio-safety cabinet and inoculated with the three days old pure culture of the fungal isolate. In every sterile flask, disc of the pectinolytic fungi isolates was added using a cork borer of $10 \mathrm{~mm}$ diameter and then plugged properly. The culture was incubated for 4 days. After incubation, the culture broth was filtered and assayed (Bezawada and Raju, 2018).

\section{Effect of Substrate Concentration on Pectinase Production}

The isolate was inoculated into each of the $50 \mathrm{~mL}$ production medium consisting of varying concentrations (i.e. $0.2,0.5,1,1.5$, and $2 \%$ ) of the extracted mango pectin in $250 \mathrm{~mL}$ Erlenmeyer flask and incubated at $30{ }^{\circ} \mathrm{C}$ in an incubator for 4 days. After incubation, each culture broth was filtered and was assayed. All pectin broth media preparations and inoculations were done.

\section{Effect of pH on the Production of Pectinase}

In this experiment, all the procedures followed in the preparation of media and inoculations were similar to those described in effect of temperature on the production of pectinase except that the incubation was done at varying $\mathrm{pH}(4.0,5.0,6.0,7.0,8.0$ and 9.0) and at fixed temperature and concentration of pectin $\left(30^{\circ} \mathrm{C}\right.$ and $1 \%$, respectively). Furthermore, assay for pectinase activity was done after 4 days of incubation (Ketipally and Ram, 2018).

\section{Data Analysis}

The data were entered into the computer and statistical analysis was done using ANOVA provided by the SAS version 9.1 and significant difference examined for different parameters and between pectinolytic fungal isolates at $95 \%$ confidence level of significance and at $\mathrm{p}$ $<0.05$

\section{RESULTS AND DISCUSSION}

\section{Yield of Extracted Mango Pectin}

In this research, pectin was extracted from mango peel with a yield of $17.75 \%$ at $\mathrm{pH} 2.2$, the temperature of $70{ }^{\circ} \mathrm{C}$ and extraction time of $60 \mathrm{~min}$ using the ethanol$\mathrm{HCl}$ method described by McCready (1970). Rehman et al. (2004) reported mango pectin extraction yields of $13.45 \%, 21.0 \%$ and $15.1 \%$ using hydrochloric acid, sulphuric acid, and nitric acid respectively at the of $\mathrm{pH}$ 2.5 , temperature $80^{\circ} \mathrm{C}$ and extraction time of $120 \mathrm{~min}$. The differences in the yields could be as a result of differences in the sources of pectin and other factors such as extraction technique, changes in $\mathrm{pH}$, temperature, extraction time and environmental factors (Kertesz 1951; Rehman et al., 2004).

Table 1. Experimental observation yield of extracted mango pectin.

\begin{tabular}{lll}
\hline Contents & Unit & Value \\
\hline Solution of Ph & - & $2.2 \pm 0.1$ \\
Volume taken for extraction & $\mathrm{mL}$ & 800 \\
Amount of mango peel sample added & $\mathrm{G}$ & 100 \\
Amount of sodium hexametaphosphate added & $\mathrm{G}$ & 12 \\
Extraction temperature & ${ }^{\circ} \mathrm{C}$ & 70 \\
Extraction time & $\mathrm{Min}$ & 60 \\
Amount of pectin obtained & $\mathrm{G}$ & 17.75 \\
Yield of pectin obtained & $\%$ & 17.75 \\
\hline
\end{tabular}

\section{Isolation and Screening of Pectinase Producing Fungi}

In total, two isolates were identified from soil samples that contain mango peel. Based on the colony characteristics the fungi exhibited on the selective growth media, the two isolates were assigned the codes $\mathrm{P}_{1}$ and $\mathrm{P}_{2}$ for further characterization and identification purpose. Figure 1 shows microscopic photographs of the two fungal isolates. The isolates were identified based on their microscopic features.

Table 2. Identification of pectinolytic fungal based on their colony morphology, growth characteristics, microscopic features and growth at temperature of $35^{\circ} \mathrm{C}$.

\begin{tabular}{|c|c|c|c|c|}
\hline $\begin{array}{l}\text { Code of the } \\
\text { isolate }\end{array}$ & $\begin{array}{l}\text { Colony characteristics on pectin agar } \\
\text { media }\end{array}$ & $\begin{array}{l}\text { Growth on Petri Plate } \\
(85 \times 15 \mathrm{~mm} \text { diameter })\end{array}$ & Microscopic features & $\begin{array}{l}\text { Probable } \\
\text { Identity }\end{array}$ \\
\hline P1 & $\begin{array}{l}\text { Moderately growing colonies with carbon } \\
\text { black /deep brownish black colour conid } \\
\text { i.a e.; reverse-colorless to pale yellow, } \\
\text { exudates lacking produced a submerged } \\
\text { form of mycelium }\end{array}$ & $\begin{array}{l}\text { Covered the plate in } 8 \\
\text { days }\end{array}$ & $\begin{array}{l}\text { Conidial heads radiate, vesicles } \\
\text { nearly globose, conidiophores up } \\
\text { to } 3 \mathrm{~mm} \text { in length, phialides } \\
\text { biseriate }\end{array}$ & $\begin{array}{l}\text { Aspergillus } \\
\text { niger }\end{array}$ \\
\hline $\mathrm{P} 2$ & $\begin{array}{l}\text { Rapidly spreading, colonies are colorless } \\
\text { to yellow or velvety, dull blue-green, } \\
\text { reverse colourless to varying g in shades, } \\
\text { produces tufted aerial mycelium up to } \\
\text { felted floccose forms }\end{array}$ & $\begin{array}{l}\text { Covered the plate in } 7 \\
\text { days }\end{array}$ & $\begin{array}{l}\text { Conidial heads columnar, } \\
\text { densely crowded, flask-shaped } \\
\text { vesicles, conidiophores short in } \\
\text { length, and phialides uniseriate. }\end{array}$ & $\begin{array}{l}\text { Aspergillus } \\
\text { fumigates }\end{array}$ \\
\hline
\end{tabular}




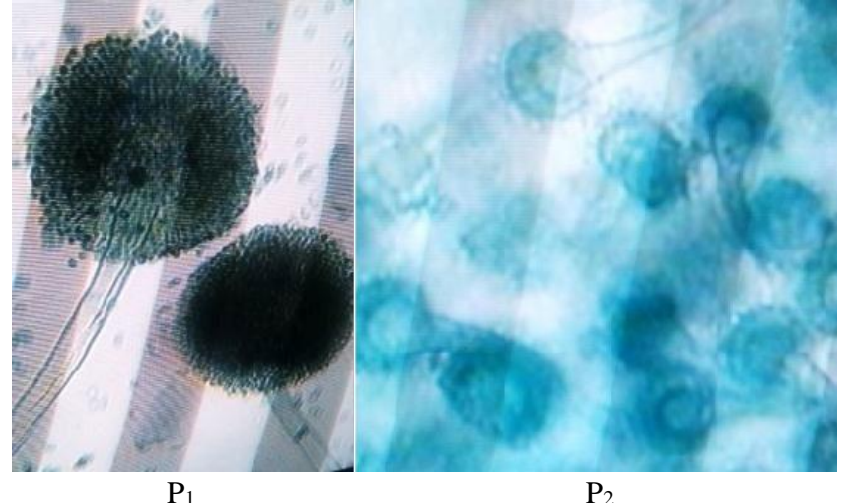

Figure 1. Micrograph of pectinolytic fungal isolate (40X).

\section{Production of Pectinases by Submerged Fermentation (SmF)}

Pectinase production increase with the increase in time duration up to $96 \mathrm{hr}$ then it decreases (Table.3). The maximum production of both isolates occurs on $4^{\text {th }}$ day ( $96 \mathrm{hr}$ ) incubation period. Production of pectinase exhibited the highest enzyme activity of $\mathrm{P}_{1}$ and $\mathrm{P}_{2}$ was at $0.0276 \pm 0.0015$ and $0.0290 \pm 0.0107 \mathrm{U} / \mathrm{mL}$ respectively. From the two isolates, $\mathrm{P}_{2}$ showed relatively maximum pectinolytic activity; therefore, Isolate $\mathrm{P}_{2}$ was used for further studies of pectinase optimization and characterization.

Table 3. Effect of incubation period on enzyme production.

\begin{tabular}{lll}
\hline $\begin{array}{l}\text { The incubation } \\
\text { period (days) }\end{array}$ & $\begin{array}{l}\text { Isolated } \\
\text { pectinolytic }\end{array}$ & $\begin{array}{l}\text { fungi enzyme } \\
\text { activity } \mathbf{U} / \mathbf{~ m L}\end{array}$ \\
\cline { 2 - 3 } & $\mathbf{P}_{\mathbf{1}}$ & $\mathbf{P}_{\mathbf{2}}$ \\
\hline 1 & $0.0144 \pm 0.0012^{\mathrm{d}}$ & $0.0145 \pm 0.0009^{\mathrm{c}}$ \\
2 & $0.0170 \pm 0.0011^{\mathrm{dc}}$ & $0.0209 \pm 0.0021^{\mathrm{abc}}$ \\
3 & $0.0177+0.0014^{\mathrm{c}}$ & $0.0219 \pm 0.0020^{\mathrm{abc}}$ \\
4 & $0.0276+0.0015^{\mathrm{a}}$ & $0.0290 \pm 0.0107^{\mathrm{a}}$ \\
5 & $0.0258 \pm 0.0006^{\mathrm{a}}$ & $0.0259 \pm 0.0076^{\mathrm{a}}$ \\
6 & $0.0218 \pm 0.0029^{\mathrm{b}}$ & $0.0259 \pm 0.0076^{\mathrm{ab}}$ \\
7 & $0.0171 \pm 0.0018^{\mathrm{dc}}$ & $0.0162 \pm 0.0005^{\mathrm{bc}}$ \\
\hline
\end{tabular}

- $\mathrm{P}_{1}=$ Pectinolytic fungal isolate one

- $\mathrm{P}_{2}=$ Pectinolytic fungal isolate two

- Values are mean \pm S.D. of 3 replicates

- a,b,c,d Means within a column with values followed by different superscripts are significantly different at $(\mathrm{P}<0.05)$, Values followed by same superscripts are not significantly different at $(\mathrm{P}<0.05)$.

\section{Determination of Optimum Temperature Required for Pectinase Production by $\mathbf{P}_{2}$.}

The experiment was run at various temperatures between 25 and $55{ }^{\circ} \mathrm{C}$ (Table 4). $35{ }^{\circ} \mathrm{C}$ temperatures were the most suitable temperature for the growth and production of pectinase activity. Maximum enzyme activity $0.0298 \pm 0.00047 \mathrm{U} / \mathrm{mL}$ was found at $35^{\circ} \mathrm{C}$ and lower activity $0.0020 \pm 0.0013 \mathrm{U} / \mathrm{mL}$ was showed at $55^{\circ} \mathrm{C}$. Any increase in temperature above $35^{\circ} \mathrm{C}$ affects metabolic activities of the microorganism which results in reduced enzyme production.

Table 4. Effect of temperature on pectinase production.

\begin{tabular}{ll}
\hline Temperature $\left({ }^{\circ} \mathbf{C}\right)$ & EnzymeactivityU/ml \\
\hline 25 & $0.0093 \pm 0.00034^{\mathrm{c}}$ \\
30 & $0.0292 \pm 0.0107^{\mathrm{a}}$ \\
35 & $0.0298 \pm 0.00047^{\mathrm{a}}$ \\
40 & $0.0211 \pm 0.0021^{\mathrm{b}}$ \\
45 & $0.027 \pm 0.0024^{\mathrm{ab}}$ \\
50 & $0.0024 \pm 0.0010^{\mathrm{c}}$ \\
55 & $0.0020 \pm 0.0013^{\mathrm{c}}$ \\
\hline
\end{tabular}

Determination of Optimum Concentration of Mango Pectin Required for Pectinase Production by $\mathbf{P}_{2}$.

The effect of substrate concentration for pectinase production $\mathrm{P}_{2}$ was incubated at different concentration of mango pectin as $0.1,0.2,0.5,1.0,1.5$ and $2 \%$ (Fig.2). Enzyme production increased with increase in concentration. A slight decrease in enzyme production was observed until the concentration reached $2 \%$. The maximum $0.013109 \mathrm{U} / \mathrm{mL}$ enzyme production was observed at $1.5 \%$ of mango pectin.

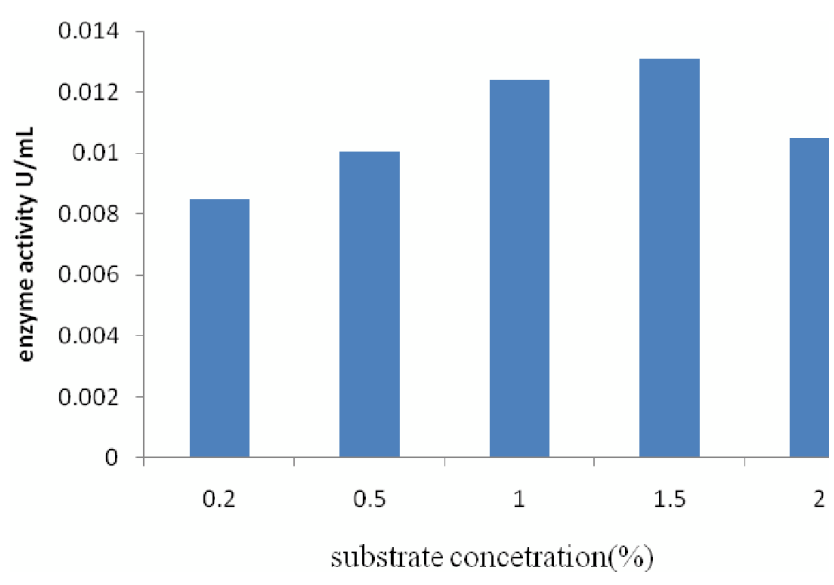

Figure 2. Pectinase production by $\mathrm{p} 2$ versus substrate concentration.

Determination of Optimum pH Required for Pectinase Production by $\mathbf{P}_{2}$.

The $\mathrm{pH}$ of the growth medium was found to have a marked effect on pectinase production (Table 5). The highest enzyme yield was observed at $\mathrm{pH}$ 6.0. $\mathrm{pH}$ alters enzyme conformation, recognition site, active site, and substrate conformation, and hence determining its optimum value. This is very critical in biochemical characterization of enzymes (Palmer, 1995). 
Table 5. Effect of $\mathrm{pH}$ pectinase production.

\begin{tabular}{ll}
\hline $\mathbf{p H}$ & Enzyme activity U/ml \\
\hline 4 & $0.0095 \pm 0.00091^{\mathrm{bc}}$ \\
5 & $0.0100 \pm 0.00093^{\mathrm{b}}$ \\
6 & $0.0123 \pm 0.00036^{\mathrm{a}}$ \\
7 & $0.0122 \pm 0.00037^{\mathrm{a}}$ \\
8 & $0.0086 \pm 0.00037^{\mathrm{c}}$ \\
9 & $0.0096 \pm 0.0011^{\mathrm{bc}}$ \\
\hline
\end{tabular}

\section{SUMMARY AND CONCLUSIONS}

An abundant amount of waste materials are produced by agricultural and fruit processing industries, which pose considerable disposal problems and ultimately leads to pollution. Vast varieties of microorganisms are present in the environment which can be exploited for the utilization of waste materials. For example in the processing of mango fruits, a large proportion of the produced wastes are in the form of peel. These peels contain substantial amounts of pectin.

From these investigations, it is evidenced that the mango peels with $17.75 \%$ pectin content were successfully used to encourage the production of pectinase under submerged fermentation process. The pectin extracted from mango peels act as the inducer for the production of pectinase enzyme.

Microorganisms serve as a major source of enzyme. Even the majority of industrial enzymes are of microbial origin. Thus an attempt of the present study is to isolate and screen for potential producers of pectinase from microorganisms. Total two pectinolytic fungi isolates were identified as the efficient producer between them screening pectinolytic fungi isolate $\mathrm{P}_{2}$ was found as efficient producers.

In order to obtain high yields of pectinases, it is essential to optimize the fermentation medium used for pectinase production. Isolate $\mathrm{P}_{2}$ was grown for different temperature, $\mathrm{pH}$, time and substrate concentration because it is essential to maximize optimum condition for production.

The evidence from this study suggests that, it is highly promising to use pectin extracted from mango peels as a substrate for the production of pectinases in a submerged fermentation system using $\mathrm{p}_{2}$ isolate and a high extent solve the problem of environmental pollution by reducing mango wastes (peels).

Acknowledgments: We are thanks to Haramaya University Laboratory Management Directorate (HULMD) and the School of Animal and Range Sciences for providing all the required laboratory facilities. We are also grateful to Mr. Yimeslal Atnafu, Ms. Yehararwork Abebaw and Mr. Dilnessa Baile for their technical assistance.
Conflict of interest: The authors declares that there are no conflicts of interest concerning the publication of this article.

\section{REFERENCES}

Adrio, J. L. and A. L. Demain. (2014). Microbial Enzymes: Tools for Biotechnological Processes. Biomolecule, 4(1): 117-139.

Bezawada, P. and Raju, K.J. (2018). Screening of pectinolytic fungi and optimization of process parameters using guava peel powder as substrate under solid state fermentation. International Journal of Engineering Science Invention, 7 (10):43-47.

Ezugwu, A.L., Eze, S.O.O., Chilaka, F.C. and Anyanwu, C.U. (2013). Production and characterization of pectinases obtained from Aspergillus fumigatus in submerged fermentation system using pectin extracted from mango peels as carbon source. Plant Products Research Journal, 16(1): 47-53.

Ezugwu, A.L., Ezike, T.C., Ibeawuchi, A.N., Nsude, C.A., Udenwobele, D.I., Eze, S.O.O., Anyawu, C.U. and Chilaka, F.C. (2014). Comparative studies on pectinases obtained from Aspergillus fumigatus and Aspergillus Niger in submerged fermentation system using pectin extracted from mango, orange, and pineapple peels as carbon sources. Nigerian Journal of Biotechnology, 28(1): 26-34.

Gurung, N., S. Ray, S. Bose and V. Rai. (2013). A Broader View: Microbial enzymes and their relevance in industries, medicine, and beyond. Biomedical. Res. Int., 2013: 1-18.

Jayani, R.S., Saxena, S. and Gupta, R. (2005). Microbial pectinolytic enzymes: a review. Process Biochemistry, 40(9): 2931-2944.

Kertesz, Z.J. (1951). The pectic substance. Inter science Publishers, New York, 68.

Khan, A., Sahay, S. and Rai, N. (2012). Production and optimization of Pectinase enzyme using Aspergillus Niger strains in Solid State fermentation. Research in Biotechnology, 3(3): 19-25.

Klich, M.A. (2002). Identification of common Aspergillus species. Centraalbureau voor schimme lcultures

Kumar, Y.S., Varakumar, S. and Reddy, O.V.S., (2012). Evaluation of antioxidant and sensory properties of mango (Mangifera indica L.) wine. CyTA-Journal of Food, 10(1):1220.

Martin, N., Souza, S.R.D., Silva, R.D. and Gomes, E. (2004). Pectinase production by fungal strains in solid-state fermentation using agro-industrial bio product. Brazilian Archives of Biology and Technology, 47(5): 813-819.

McCready, R.M. (1970). Methods on Food Analysis. Academic Press, New York.

Meena, K.K., Jaipal, M.K. and Singh, U. (2015). Production kinetics and characterization of pectinase enzyme from Aspergillus Niger. South Asian Journal of Food Technology and Environment, 1(2):131-135.

Miller, G.L., (1959). Use of dinitrosalicylic acid reagent for determination of reducing sugar. Ana lytical Chemistry, 31(3): 426-428.

Murthy, P.S., and Naidu, M.M. (2010). Protease production by Aspergillus oryzae in solid-state fermentation utilizing coffee by-products. World Applied Sciences Journal, 8(2): 199-205. 
Neeta, R., Anupama, S., Anjuvan, S. and Giridhar, S. (2011). Production of polygalacturonase and pectin methylesterase from agro waste by using various isolation of Aspergillus Niger. Insight Microbiology, 1(1):1-7.

Palmer, T. (1995). Understanding Enzymes. Ellis Horwood Ltd. England. 104: $352-365$.
Rehman, Z.U., Salariya, A.M., Habib, F. and Shah, W.H. (2004). Utilization of mango peels as a source of pectin. JournalChemical Society of Pakistan, 26:73-76.

Wang, G., Michailides, T.J. and Bostock, R.M. (1997). Improved detection of polygalacturonase activity due to Mucor piriformis with a modified dinitrosalicylic acid re agent. Phytopathology, 87(2): 161-163. 
THIS PAGE INTENTIONALLY LEFT BLANK 